\title{
Historical methods in the social sciences: Commentary on Schoemaker 2020
}

\author{
Johann Peter Murmann
}

Institute of Management and Strategy, University of St Gallen, St Gallen, Switzerland

Correspondence: Johann Peter Murmann, Management and Strategy University of St Gallen, Dufoustr. 40 a, St Gallen 9000 , Switzerland. Email: peter.murmann@unisg.ch

Schoemaker (2020) has written a thought-provoking essay, juxtaposing what many would regard as radically distinct intellectual enterprises: analyzing the past and creating scenarios about the future. Schoemaker points out that most historians are reluctant to extrapolate from their work and offer predictions about the future. The wonderful quip, "It's difficult to make predictions, especially about the future" ${ }^{1}$ encapsulates the reason why professional historians-almost as a professional badge of honor and good practice-shy away from making predictions about the future. No doubt, it is much easier to narrate a story where you know what the outcome is than provide a narrative about how the future will turn out. This it not only because the past is closed in terms of what can happen while the future remains open. ${ }^{2}$ As Schoemaker (2020, p. 2) suggests, our brains are much better able to come up with a causal story for an event that is framed as having already occurred than developing a causal story for an event that is merely framed as one out of many possible future outcomes.

Schoemaker spent his scholarly career writing about decision-making and has been a leader in developing scenario planning techniques that are intended to help organizations navigate the challenges of an uncertain future. As a teacher of business strategy, I have been a user rather than a contributor to the scenario planning literature. As Schoemaker (2020), I see the essence of scenario planning as not promising to offer exact probabilities about what scenario will unfold, but to enable organizations to become better equipped for change when the future turns out to be a non-linear break from past. From a strategic management point of view, a key task is to instill into an organization the ability to change or cultivate "organizational resilience" as Schoemaker (2020, p. 5) and others call it. For companies, the promise of investing in a scenario-planning exercise is precisely that by developing and socializing often extreme stories about alternative futures, members of the organization become much more ready to change when the environment shifts radically. If a firm before January 2020 had seriously played through the possibility of a pandemic where large parts of the world economy would shut down and had developed a blueprint for dealing with it, advocates of scenario planning believe that such a firm would have been more successful in navigating the pandemic than others that had never subjected its members through such a scenario exercise. ${ }^{3}$

"How historical analysis can enrich scenario planning" appears to be Schoemaker's first writing about how historical methods can aid scenario techniques, adding to a growing literature on the topic (Bradfield, Derbyshire, \& Wright, 2016). To give some context to my comments, I want to offer a bit background on my own intellectual journey. Even though I was trained as management scholar (I suspect in very similar ways as Schoemaker), my desire to understand better how firms gain and loose competitive advantage over time and how technologies evolve over long periods has led me-starting with my dissertation-to frequently use historical methods (e.g. Murmann, 2003). I found it difficult to extract much insight about causal process by simply running regression equations on datasets, but found such insights in the writings of business (e.g. Chandler, 1990; Reader, 1970) and technological historians (e.g. Aitken, 1976; Constant, 1980). ${ }^{4}$ Inspired by the work of Tetlock \& Gardner (2015) and his collaborative writings with Tetlock (Schoemaker and Tetlock,2016), I have recently begun to marry forecasting tournaments and scenario planning exercises, hoping to implement a novel foresight instrument into a company's strategic planning process. Schoemaker and I seem to have in somewhat opposite directions, me towards scenario planning and him toward historical writings. Not surprisingly, I was curious to find out how Schoemaker would portray the field of history and identify its value for scenario planning.

Schoemaker's entry point for his essay is that historians and scenario planners create narratives. It is therefore reasonable to explore whether scenario planners can learn from historians in their quest to build productive scenarios. He has read widely on the variety of historical methods. In my view he has synthesized a diverse field in very useful manner and gives an effective comparative assessment of historical analysis and scenario planning. If I would recommend one book to scenario planning practitioners in particular to learn more about the variety of historical approaches (from the many contributions that 
Schoemaker draws from) it would be "The Landscape of History: How Historians Map the Past" (Gaddis, 2002). Gaddis's short book builds on previous efforts (e.g. Bloch, 1953; Braudel, 1982) but is much more reader-friendly because Gaddis is a particularly gifted writer and his book is explicitly written for a broader audience and not just for other professional historians. In my view, Schoemaker is appropriately measured in his conclusions. He acknowledges that it will not be a trivial undertaking to import best practices of historians into the field of scenario planning.

I would like to draw attention to two subfields sitting between history and the social sciences where this has already been done. They perhaps can serve as a role model for scenario planning. One is evolutionary economics (Nelson, Dosi, \& Helfat, 2018; Nelson $\&$ Winter, 1982) and the other is comparative historical sociology (Mahoney \& Rueschemeyer, 2003; Tilly, 1984, 1997). Scholars in both fields believe that the respective branch of social science (economics and sociology) can only make progress if it is deeply grounded in historical realities and if it can provide convincing causal accounts how economies and societies have changed over time. In these two subfields, evolutionary biology is seen as a more appropriate explanatory model than Newtonian physics.

Evolutionary economist also run counter-factual historical computer simulations similarly to some branches of scenario analysis to test whether the causal stories implicit in the histories of specific industries hold up when the "history" of the industry is re-run many times with similar and slightly different starting conditions (Brenner \& Murmann, 2016; Malerba, Orsenigo, \& Winter, 2016). One key goal of such "history friendly" simulations is to make causal narratives about the industry much more robust. When I, for example, subjected my comparative history on the synthetic dye industry (Murmann, 2003) to a simulation analysis with Brenner \& Murmann (2016), we found that my arguments that Germany caught up with France and Great Britain because of a larger availability of organic chemists held up while my arguments about the causal power of differences in patent laws across countries could not be confirmed.

Comparative historical sociologists use a powerful tool: to search for causally deep analogies among cases. ${ }^{5}$ The goal is to try to figure out the causal structure behind events and outcomes such as social revolutions or success and failure of organizations. Stinchcombe (1978), comparing scholarship on the French and the later Russian revolution, explains, "[...] if general concepts consist in the analogies between elements and if they are deeper if the analogies are deeper, then the basic investigatory task of concept formation is the deepening of analogies. [...] Far from it being the case that the most powerful general theorists ignore details, the precise opposite is true" (p. 21). Stinchcombe goes on arguing that deep analogies are built by carefully comparing different cases and asking whether they are sufficiently similar to lead to the same causal outcomes. Schoemaker touches on the usefulness of analogies when he writes that the four scenarios about South Africa could have been made more realistic by looking at the experience of other countries at different historical moments. Based on my own work (Murmann, 2003), I can testify that comparing in detail carefully constructed firm case studies is a very effective way to get a deeper understanding of why some firms succeeded when other failed. Schoemaker mentions in passing that Shell missed the fracking revolution despite being a lead user of scenario planning. To understand more deeply why Shell missed this alternative source of oil and gas, one would look for companies that did not miss the opportunity (e.g. the independent gas company Mitchel) and then search for other firms that missed it (all major oil companies as far I can tell) and other firms that quickly jumped onto the opportunity (other independent gas companies). One might even look entirely outside this particular time and industry and study cases where incumbent firms missed a major trend and when not. This would allow one to develop deeper causal explanations for under what circumstances firms might see a technological or market revolution and under what circumstances are less likely to do. I agree with Schoemaker that scenario planners would probably benefit from searching for deep analogies in different historical times and places when they construct narratives about the future.

\section{ORCID}

Johann Peter Murmann (iD https://orcid.org/0000-0003-1631-3012

\section{ENDNOTES}

1 https://quoteinvestigator.com/2013/10/20/no-predict/

2 Clearly, the past remains open in an interpretive sense. New generations may reinterpret the past and how the past influences the present can certainly change as Schoemaker (2020) also points out.

3 Public health officials, the executive branch of the US government in 2014 (https://bit.ly/3eltjav) and Bill Gates in 2015 knew that a virus pandemic was a high probability scenario. See Bill Gates's 2015 Ted Talk (https://bit.ly/3encawW), where he is calling for more investments for being prepared for a pandemic which he saw as likely during his lifetime.

4 For a more detailed account of why I turned from the typical regression only methods to historically enriched methods, see Murmann (2012).

5 An eye-opening example of the power of using analogies for is the scientific work of Kepler who cycled through endless analogies to finally end up being able to explain why planets would travel in predictable elliptical and not perfectly circular pathways around the sun. See Epstein (2019, Chapter 5) for a wonderful description of Kepler's analogical reasoning.

\section{REFERENCES}

Aitken, H. G. J. (1976). Syntony and spark: The origins of radio. New York: John Wiley \& Sons.

Bloch, M. (1953). The historian's craft. New York: Vintage Books.

Bradfield, R., Derbyshire, J., \& Wright, G. (2016). The critical role of history in scenario thinking: Augmenting causal analysis within the intuitive logics scenario development methodology. Futures, 77, 56-66. https://doi.org/10.1016/j.futures.2016.02.002

Braudel, F. (1982). On history, Chicago: University of Chicago Press.

Brenner, T., \& Murmann, J. P. (2016). Using simulation experiments to test historical explanations: The development of the German dye industry 1857-1913. Journal of Evolutionary Economics, 26(4), 907-932. 
Chandler, A. D. (1990). Scale and scope: the dynamics of industrial capitalism. Cambridge: Harvard University Press.

Constant, E. W. T. I. (1980). The origins of the turbojet revolution. Baltimore: The Johns Hopkins University Press.

Epstein, D. (2019). Range: Why Generalists Triumph in a Specialized World, New York: Riverhead Books.

Gaddis, J. L. (2002). The landscape of history: How historians map the past. New York: Oxford University Press.

Mahoney, J., \& Rueschemeyer, D. (2003). Comparative historical analysis in the social sciences. Cambridge, UK; New York: Cambridge University Press.

Malerba, F., Orsenigo, L., \& Winter, S. G. (2016). Innovation and the evolution of industries: History-friendly models, Cambridge, UK: Cambridge University Press.

Murmann, J. P. (2003). Knowledge and competitive advantage: The coevolution of firms, technology, and national institutions. New York: Cambridge University Press.

Murmann, J. P. (2012). Marrying history and social science in strategy research. In S. Kahl, B. Silverman, \& M. Cusumano (Eds.), History and strategy (Advances in Strategic Management, Volume 29) (pp. 89-116). Bingley, UK: Emerald Group Publishing Limited.

Nelson, R. R., Dosi, G., \& Helfat, C. E. (2018). Modern evolutionary economics: An overview, Cambridge, UK: Cambridge University Press.

Nelson, R. R., \& Winter, S. G. (1982). An evolutionary theory of economic change. Cambridge, MA: The Belknap Press of Harvard University Press.
Reader, W. J. (1970). Imperial chemical industries: A history, Vol. I. London: Oxford University Press.

Schoemaker, P. J. H. (2020). How historical analysis can enrich scenario planning. Futures \& Foresight Science, 1-13. https://doi.org/10.1002/ ffo2.35

Schoemaker, P. J. H., \& Tetlock, P. E. (2016). Superforecasting: How to upgrade your company's judgment. Harvard Business Review, 94, 72-78.

Stinchcombe, A. L. (1978). Theoretical methods in social history. New York: Academic Press.

Tetlock, P. E., \& Gardner, D. (2015). Superforecasting: The art and science of prediction. New York: Crown Publishing.

Tilly, C. (1984). Big structures, large processes, huge comparisons. New York: Russell Sage Foundation.

Tilly, C. (1997). Roads from past to future (With a review essay by Arthur Stinchcombe). Lanham: Rowman \& Littlefield.

How to cite this article: Murmann JP. Historical methods in the social sciences: Commentary on Schoemaker 2020. Futures \&

Foresight Sci. 2020;2:e55. https://doi.org/10.1002/ffo2.55 